\title{
A fókuszált lézernyaláb keresztmetszeti jellemzőinek szerepe az impulzusos üzemü lézeres vágásnál
}

\section{Role of the Features of Focused Laser Beam in Pulsed Laser Cutting}

\author{
Meszlényi György, ${ }^{1}$ Bitay Enikő2, 3 \\ ${ }^{1}$ Óbudai Egyetem, Budapest, Magyarország, meszlenyi.gyorgy@kvk.uni-obuda.hu \\ ${ }^{2}$ Sapientia Erdélyi Magyar Tudományegyetem, Marosvásárhelyi Kar, Marosvásárhely, Románia \\ ${ }^{3}$ Erdélyi Múzeum-Egyesület, Müszaki Tudományok Szakosztálya, Kolozsvár, Románia, bitay@eme.ro
}

\begin{abstract}
In this article investigation of the roles of two important factors of focused laser beam, the focal spot diameter and the Rayleigh length as determining variables of the beam quality were analysed. The equations of these two factors are based on those most commonly used in the literature. The exchange between three different beam quality numbers were shown. It is proven on the basis of the scientific literature, that the beam quality degrades compared to the original data given by the factory of laser. The causes of the beam quality degradation are lens aberrations in the optical path of the given laser, and the shifting of the beam propagation ratio $\left(\mathrm{M}^{2}\right)$ to higher values. A new equation for estimation of the new, lowest value for $\mathrm{M}^{2}$ factor is presented, based on the comparison of the laser cut material thickness to the depth of focus, which is two times the Rayleigh length.
\end{abstract}

Keywords: laser cutting, laser beam, beam diameter, beam quality, beam propagation ratio $\left(M^{2}\right)$, Rayleigh length.

\section{Összefoglalás}

Jelen cikkben a fókuszált lézernyaláb keresztmetszete két fontos jellemzőjének, a fókuszfoltátmérőnek és a Rayleigh-hossznak mint a szakirodalomban legelterjedtebb képleteiben szereplő változóknak a hatását elemeztük. A mindkét képletben szereplő, a nyalábminőséget kifejező változók egymásba való átváltását ismertetjük, és a szakirodalom alapján bebizonyítjuk, hogy a lézereknél a gyárilag megadott értékekhez képest a lézernyaláb optikai sugármenetében lévő lencsék hibái miatt a nyalábminőség romlani fog, tehát az $M^{2}$ tényező értéke nő. A megnövekedett $M^{2}$ változó alsó határának becslésére bemutatunk egy új összefüggést, mely az átvágott anyagvastagság és a kétszeres Rayleigh-hossz mint fókuszmélység egyeztetésén alapul.

Kulcsszavak: lézersugaras vágás, nyalábkeresztmetszet, nyalábátmérő, nyalábminőség, Rayleigh-hossz.

\section{Bevezetés}

Lézersugaras megmunkálásnál fontos szerep jut a megmunkáló lézernek, ezen belül a fókuszált nyaláb keresztmetszeti jellemzőjének, a fókuszfoltátmérőnek, mert a fókuszált nyaláb az az érintésmentesen dolgozó szerszám, mely energiaátadás útján a megmunkálást végzi. Miért fontos tudni, hogy mekkora a fókuszfoltátmérő? Mert ki- sebb fókuszfoltátmérővel lézersugaras vágásnál kisebb vágási rés, emiatt kisebb salakmennyiség érhető el, tehát jobb vágási minőséget kapunk, kevesebb utómegmunkálásra van szükség. A kevésbé szétterülő nyaláb miatt a hőhatásövezet is kisebb. A fókuszfolt átmérőjének képletei több szakirodalomban megegyeznek, csak a közös formátum eléréséhez néhol meg kell duplázni a 
sugarat, hogy az átmérőt megkapjuk, és a nyalábminőség-adatokat át kell számítani: a K nyalábterjedési tényező reciprokját, az $M^{2}$ nyalábminőség tényezőt beírva a képletbe (ld. 2. pont) [1], [2], [3], [4]:

$$
d_{f 0}=\frac{4 \lambda f M^{2}}{\pi d_{b}}
$$

Itt $\lambda$ a lézer hullámhossza, $f$ a lézernyalábot a munkadarabra fókuszáló lencse fókusztávolsága, $M^{2}$ a nyalábminőség tényező, mely megmondja, hogy az ideális Gauss-nyalábhoz képest hányszoros a vizsgált nyalábnak a fókuszfoltátmérője, $d_{b}$ a fókuszálólencse előtti közel kollimált lézernyaláb átmérője. Ha a fókuszáló lencsére eső közel kollimált lézernyalábot tágítjuk, akkor az alul szereplő $d_{b}$ nyalábátmérő szorzódik a nyalábtágító faktorával, vagyis egy mértékegység nélküli számmal $\left(B_{e}\right)$, ami megmondja, hogy hányszorosa lett a nyaláb átmérője a tágítatlanhoz képest [1]:

$$
d_{f 0}=\frac{4 \lambda f M^{2}}{\pi d_{b} B_{e}}
$$

A Rayleigh-hossz a nyalábterjedés irányában a fókuszsíktól mért azon hossz, amely végén a lézerfolt területe duplájára, így a nyaláb rádiusza gyök kettőszeresére nő, ezért a felületegységre jutó impulzusenergia a felére esik vissza a fókuszfoltban számíthatóhoz képest. Általában a Rayleigh-hossz kétszeresén belül tekintik fókuszban levőnek a nyalábot, ezt nevezzük fókuszmélységnek, tehát ha lézeres vágásról van szó, körülbelül ilyen vastag anyagot tud átvágni a lézer. Képlete nagyon hasonló a lézerfoltátmérő képletéhez, csak itt a fókuszálólencse fókusztávolsága és a lencse előtti nyalábátmérő a négyzeten szerepel [1], [4]:

$$
z_{r}= \pm \frac{4 \lambda M^{2} f^{2}}{\pi d_{b}^{2} B_{e}^{2}}
$$

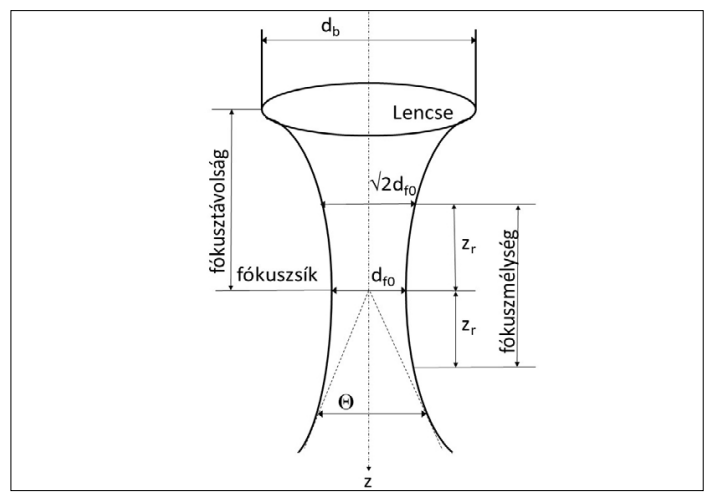

1. ábra. A fókuszált lézernyaláb eddig tárgyalt jellemzőinek szemléltetése
A fókuszált lézernyaláb eddig tárgyalt jellemzőit az 1. ábra szemlélteti, ahol a z-koordináta a lézernyaláb terjedési irányába mutat, $\Theta$ a fókuszált nyaláb széttartási szöge. Az 1. ábra az [1] és az [5] szakirodalom ábráinak egyesített jellemzői alapján készült. A nyalábminőséget tárgyalják a következő cikkek: [6], [7], [8], [9].

\section{A nyalábminőség mérőszámai}

A fókuszált nyalábkeresztmetszet két legfontosabb jellemzője a fókuszfoltátmérő és a Rayleighhossz definíciójában szereplő nyalábminőség tényező. Jó, ha tudjuk, milyen megadási módjai vannak a nyalábminőségnek, és azt is, hogyan lehet ezeket egymásba átváltani.

A nyalábparaméter szorzat $(B P P)$ a lézernyaláb fókuszálhatóságát fejezi ki, melyet leggyakrabban a rezonátorbeli nyalábderéksugár és a távoli mező divergenciaszöge, $\Theta_{\sigma}$ szorzataként adnak meg, amit 4-gyel elosztanak. Itt $\Theta_{\sigma}$ : a táguló nyalábot burkoló aszimptotikus kúp nyílásszöge [10]:

$$
B P P=\frac{d_{\sigma 0} \Theta_{\sigma}}{4}
$$

A harmadik megadási mód a nyalábminőség tényező, annak a mértéke, hogy mennyire közelíti meg a nyalábparaméter szorzat az ideális Gauss-nyaláb diffrakciós határát [10]:

$$
M^{2}=\frac{\pi}{\lambda} \frac{d_{\sigma 0} \Theta_{\sigma}}{4}
$$

A másik megadási mód a $\mathrm{K}$ nyalábterjedési tényező, mely $M^{2}$ reciproka: [10].

$$
K=\frac{1}{M^{2}}
$$

$M^{2}$ nem ideális nyalábra $>1$, és $\mathrm{K}<1$. A fenti képletekből következik, hogy ha a három, a nyalábminőséget jellemző változóból egy adva van, akkor a többi ebből számolható, de ehhez a lézer hullámhosszát is kell tudni, és a mértékegységek átváltására oda kell figyelni.

\section{A nyalábminőség tényező lehetséges változásának hatása fókusz-foltátmé- rőre és a Rayleigh-hosszra.}

Előrebocsátom, hogy a nyalábminőség tényező méréséről az ISO11146 szabvány rendelkezik. A korrekt méréshez „a fókusz környezetében, a sugártengely mentén legalább tíz helyen meg kell mérni a lézernyaláb $d(z)$ átmérőjét. A mérési helyek felének a Rayleigh-hosszon $\left(z_{R}\right)$ belülre kell esnie, a másik felének a Rayleigh-hossz két- 
szeresén kívül” [11]. A nyalábminőség tényező és a fókuszált nyalábkeresztmetszet méréséhez e dolgozatban vizsgált impulzusos üzemü lézereknél a nem folyamatos lézerműködés miatt nem használhatóak az egyszerübb késélszkennelő vagy részszkennelő módszerek, hanem mátrixérzékelős detektorra, illetve a detektor nagy érzékenysége miatt többfokozatú nyalábgyengítésre van szükség, olyan módon, ami nem befolyásolja a mérés eredményét: nem torzítja az eredetileg mérendő nyaláb jellemzőit [11]. Ezek nagyon drága eszközök, egy ilyen eszköz ingyenes használatáról tárgyaltunk a tulajdonos céggel. Sajnos ilyen feltételek mellett ingyenes kiszállás, eladás lehetősége nem áll fenn, nem álltak szóba velünk.

Amit az alábbiakban be szeretnénk mutatni: milyen a nyalábminőség tényező lehetséges változásának hatása a fókuszfoltátmérőre és a Rayleighhosszra. Ez a fent röviden idézett valóság egy leegyszerúsített modellje, mely mégis hasznos eredményekhez vezet. Azért is lehet megvizsgálni ezt a közelítést, mert a vizsgált lézerek móduszszerkezete az ideális Gauss-nyalábot megközelítő TEM00 közeli a szerviz közlése alapján. Egyszerűbben kezelhető és vizsgálható így a fókuszált nyalábkeresztmetszet lehetséges változása, annak becslése e két mennyiség vizsgálatán keresztül. Ami még indokolja ezt az elemzést, az, hogy a lézersugaras megmunkáláskor a nyaláb fókuszfolt közeli részét használjuk, érdekes, hogy hol van a fókusz, mekkora a fókuszfoltátmérője és a kétszeres Rayleigh-hossz, amin belül dolgozni lehet a lézerrel. Milyen további előnyökkel jár a két fenti mennyiség vizsgálata? E két változó alapján függvényekkel leírható a fókuszált nyaláb geometriája: a nyalábátmérő a nyalábterjedés irányába mutató z-koordináta függvényében, ahol $z_{0}$ a fókuszsík z-koordinátája [1]:

$$
\mathrm{d}_{\mathrm{f}}(\mathrm{z})=\mathrm{d}_{\mathrm{f} 0} \sqrt{1+\left(\frac{\mathrm{z}-\mathrm{z}_{0}}{\mathrm{z}_{\mathrm{r}}}\right)}
$$

Felidézve a fókuszfoltátmérő és a Rayleigh-hossz képletét, analizáljuk, hogy mitől függ a képletek eredménye, mindkét képletben (2 és 3) ugyanazok a mennyiségek szerepelnek, ezt az analízist a korábbi cikkeinkben [12], [13], [14], [15], [16] elvégzett vágási kísérletekhez kötjük.

- A hullámhossz: a kísérletekben használt Nd:YAG lézer hullámhossza, elhanyagolható módon változik.

- A fókuszálólencse fókusztávolsága állandó: $50 \mathrm{~mm}$ volt.
- A fókuszálólencse előtti közel kollimált lézernyaláb-átmérő egyenlő a tágítatlan nyalábátmérő db szorozva a nyalábtágító szorzószámával. Be: adott nyalábtágító állásnál mindkettő konstans, a nyalábtágító hatását később vizsgálom.

- A képletekben szereplő többi tényező konstans.

Most vizsgáljuk meg a nyalábminőség tényező változásának általam megtalált eseteit, melyek általában a gyárilag megadott nyalábminőség romlását, ezzel a fókuszfoltátmérő és a Rayleigh-hossz növekedését jelzik.

Ötféle információ, amelyből arra következtetünk, hogy változik a nyalábminőség tényező:

1. A LASAG KLS 246 FC mikro megmunkálásra kifejlesztett Nd:YAG lézer hajlamos a termikus lencsézésre: nagyobb átlagteljesítménynél a kristályrúd közepe melegebb, jobban kitágul, mint a külső felülete: tehát a két vége átlagteljesítménytől függően változó görbületű lencseként müködik. Hasonló effektus került leírásra az egyik szakirodalomban: [5]. A szerviz közlése szerint $5 \mathrm{~W}$ átlagteljesítményig $M^{2}=3$, a maximális $15 \mathrm{~W}$ átlagteljesítménynél $M^{2}=5$, a kettő között lineárisan változik.

2. A zoomos 8-fokozatú nyalábtágító mint optikai rendszer legalább 3 lencséből áll, mert 2 lencse kellene a Galilei-távcső rendszerü, fix nyalábtágításúhoz. Ezeknek a lencséknek is van képhibájuk, nézzük most a legerősebb hatásút: a szférikus aberrációt. A szférikus aberráció lényege, hogy az optikai tengelytől sugárirányban eltávolodva minél kijjebb lévő gyürüt vizsgálok, annál közelebb lesz a fókusz a lencséhez, tehát a fókuszfoltátmérő megnő. A LASAG szerviz azt írta, hogy 1-es nyalábtágító állásnál vegyük ki a nyalábtágítót, hiszen ekkor az csak átengedi a kollimált nyalábot, ez is arra utal, hogy a nyalábtágító ront a fókuszálhatóságon.

3. Kaplan könyve szerint [1] erős fókuszálásnál, kis $F$-számoknál nem igazak az $r_{f 0}$ fókusz sugár és $z_{r}$ képletei, hanem korrekciókat kell bevezetni (itt $\left.F=f / d_{b}\right)$ :

$$
r_{f 0}=\frac{2 \lambda F}{\pi K}+\frac{k_{s a} d_{b}}{2 F^{2}}=\frac{2 \lambda f}{\pi d_{b} K}+\frac{k_{s a} d_{b}^{3}}{2 f^{2}}
$$

Tipikus értékek $n$ törésmutatójú lencsékre és a lencsék aberrációit korrigáló ksa faktorokra a lencse anyagától függően a következők:
ZnSe
$n=2,40, \quad k_{s a}=0,0312$
GaAs
$n=3,27, \quad k_{s a}=0,0139$

Egy dolog biztosan kiderül ebből az egyenletből: $r_{f o}$, ezzel együtt $d_{f 0}$ és $z_{r}$ értéke nagyobb 
lesz, tehát a nyaláb fókuszálhatósága romlik. Itt külön szerepel $K$ nyalábterjedési tényező és a korrekció, én ezt „belegyúrnám” $M^{2}$ tényező értékébe, mert nekem így lenne logikus, még akkor is, ha a szerző külön kezeli ezeket. A 4. pontban idézett cikkben ez a korrekció már $M^{2}$ tényezőben szerepel. Két dolog miatt azonban ezekkel a korrekciókkal nem tudok számolni: az első, hogy a szerző nem mondja meg, hol a határa az erős fókuszálásnak. Nyilván nagy lencse előtti nyalábátmérőt és kis fókusztávolságú lencsét jelent, azt sejtem, hogy a maximális nyalábtágító állás és az 50 mm-es fókuszálólencse idetartozik. A második, hogy nem ismerve a lencse anyagát, nem tudom, melyik korrekciós faktort válasszam.

4. Harp cikke [4]: A Practical method for determining the beam profile near the focal spot, mely egy rangos Springer-folyóiratban jelent meg, a fókuszált lézernyaláb elé ferdén elhelyezett anyagon hegesztési varratokat készítve elemezte az IPG Photonics gyártmányú $300 \mathrm{~W}$, CW, Ytterbium Fiber Laser nyalábminőségét. A kezdeti nyalábminőség tényező $M^{2}=1,04$ volt. A lézernyaláb $9 \mu \mathrm{m}$-es szálból lépett ki, és párhuzamosítás után 4,5 mm volt az átmérője. Ötszörös nyalábtágítót használtak a kisebb fókuszfolt elérésére, mely után három különböző fókuszálólencsét próbáltak ki, sorra: $150 \mathrm{~mm}$, $100 \mathrm{~mm}$ és $60 \mathrm{~mm}$ fókusztávolságúakat. A gyárilag megadott $M^{2}$ értéket a cikkben először a lencsék meg nem nevezett optikai hibái miatt korrigálja: itt is a lencse fókusztávolságának négyzetével oszt a korrekcióban, az „a” tényezőt a hegesztési kísérletből veszi:

$$
M^{2}=M_{0}^{2}+\frac{a}{f^{2}}
$$

A cikkben az eredményeket összesítő diagram a $60 \mathrm{~mm}$ fókuszú lencsére vonatkozóan a fenti korrekcióval a kezdeti 1,05-ös $M^{2}$ érték felmegy 2,5-re, a szférikus aberrációt is beleszámítva 6 körüli érték lesz.

5.Zimmermann cikkében [3] IPG gym. YLR-200-SM egymódusú szállézert vizsgál, a kollimált nyalábra megadja a fókuszálatlan nyalábátmérőt, az ebből kiszámolt elvi fókuszfoltátmérőt, a Rayleigh-hosszat és a teljesítménysűrüséget. De a valóságban a fókuszálólencse optikai hibái, elsősorban a szférikus aberráció megnöveli az elvileg elérhető fókuszfoltméretet. A fókuszolt átmérő a fókuszálólencse előtti nyalábátmérő köbével arányosan nő. ISO 11145 és 11146 szabvány szerinti késélszkennelő módszerrel mérték a fókuszált nyaláb változóinak értékeit. A kísérleteknél vizsgálták a lézersugár terjedési irányába eső, a lézer teljesítményétől függő fókuszeltolódást, ami 89 mikrométeres Rayleighhosszat meghaladó 110 mikrométer körüli érték volt. Ezt a fókuszeltolódást a lézert vezető optikai elemek és foglalataik felmelegedése okozza. Adatok a számoláshoz: hullámhossz: $1070 \mathrm{~nm}, M^{2}<1,1$; fókuszálólencse fókusztávolsága: $50 \mathrm{~mm}$, eredeti nyalábátmérő: $6,5 \mathrm{~mm}$ [4]. A kísérlet érdekessége, hogy a kétszeres nyalábtágítót egyszer tágítóként alkalmazták, így nagyobb lett a mért fókuszfoltátmérő, mint az elvi érték (1. táblázat 3. sor), aztán kétszeresére szűkítették a nyalábot, így az elvi értékhez képest kisebb fókuszfoltátmérőt kaptak (1. táblázat 1. sor). A szűkítés haszna, hogy nőtt a Rayleigh-hossz: vastagabb anyagot lehet megmunkálni.

A nyalábminőség romlását okozhatja a fókuszálólencse előtti védőüveg szennyeződése, melyet a munkadarabról visszafröcskölődő kicsi anyagcseppek is okozhatnak, ha ezt észleljük, ki kell cserélni a védőüveget.

1. táblázat. A [3] cikkbeli elvi kiszámolt értékek és a mérési eredmények összevetése

\begin{tabular}{|l|c|c|c|}
\hline Nyalábátmérő (mm) & 3,25 & 6,5 & 13 \\
\hline Elvi fókuszolt átmérő ( $\mu \mathrm{m})$ & 23 & 12 & 6 \\
\hline Elvi Rayleigh-hossz $(\boldsymbol{\mu m})$ & 355 & 89 & 22 \\
\hline Mért fókuszolt átmérő ( $\mu \mathrm{m})$ & 20 & 14 & 9,4 \\
\hline
\end{tabular}

\section{Az $M^{2}$ tényező romlásának becslése öt korábbi kísérletnél}

Most egy új módszert mutatunk be, mellyel $M^{2}$ tényező romlására egy alsó közelítést lehet adni a megmunkált anyagvastagság és a Rayleigh-hoszsz összehasonlításával. A korábban elvégzett öt kísérletnél LASAG KLS 246 FC lézert használtunk. A szerviz közlése alapján a lézerre $M^{2}\left(P_{a ́ t l a g}=<\right.$ $5 \mathrm{~W})=3$ és $M^{2}\left(P_{\text {átlag }}=15 \mathrm{~W}\right)=5$ és e két érték között lineáris. Ebből felírható az egyenes egyenlete $y=0,2 x+2$ ha $5<x<15$, ahol y az $M^{2}$ tényező és $x$ a $P_{\text {attlag. }}$ Az első három kísérleti megmunkálás jellemzőit bemutató táblázatban (2. táblázat) így kiszámolható az $M^{2}$ tényező, amely 3,7 és 4,2 közötti értékekre jön ki. Így a fókuszfolt mérete és a Rayleigh-hossz első közelítése kiszámolható. A Rayleigh-hossz kétszerese sokkal kisebb volt, mint az átvágott anyag vastagsága, ezért újra korrigálnom kellett az $M^{2}$ tényezőt.

A Rayleigh-hossz = az anyagvastagság $\left(v_{a}\right)$ fele 
egyenletből (3) képletet átrendezve egy új egyenletet felállítva (10) kiszámoltam az új $M^{2}$ tényező becsült értékét, ami 7 körüli értéket adott.

$$
\frac{\frac{v_{a}}{2} \pi d_{b}^{2} B_{e}^{2}}{4 \lambda f^{2}}=M_{\dot{\mathrm{u}} j}^{2}
$$

A kiszámolt új $M^{2}$ tényezővel újra kiszámoltam a fókuszfolt átmérőjét, ami 20 mikrométer körüli volt, amiben az az érdekes, hogy 8-as nyalábtágítónál kb. ekkora volt a vágási rés (2. táblázat). A kapott eredményeket szemlélteti a 2. ábra: sikerült a kísérleti eredményekhez illeszteni a modell paramétereit.

A 0,4 mm-es 4-es nyalábtágítóval végzett lemezvágási kísérletre alkalmazva a fenti gondolatmenetet az $M^{2}$ tényező a szerviz közlése alapján felállított egyenletből 3,8-4,8 közötti értékre jött ki. Az ennek alapján kiszámolt Rayleigh-hossz kétszerese most sem érte el az anyagvastagságot. A Rayleigh-hosszat egyenlővé téve az anyagvastagság felével $M^{2}$-re 5,9 jött ki, ami 1-gyel kisebb, mint a 8-as nyalábtágítónál (3. táblázat). Az eredmény megegyezik az eddig ismertetett elemzésekével, nyilván ha csökken a lencserendszereken átvezetett nyaláb átmérője, ha 8-as helyett 4-es nyalábtágító szorzót alkalmazunk, akkor csökken a szférikus hiba, tehát javul a nyalábminőség.

2. táblázat. $M^{2}$ tényező és $d_{f o}$ és $z_{r}$ elméleti és az átvágott cső anyagvastagság alapján korrigált új értékei

\begin{tabular}{|c|c|c|c|}
\hline & $\begin{array}{c}\text { 1. kísérlet } \\
\text { [8] }\end{array}$ & $\begin{array}{c}\text { 2. kísérlet } \\
\text { [9] }\end{array}$ & $\begin{array}{l}\text { 3. kísérlet } \\
\text { [10] }\end{array}$ \\
\hline $\begin{array}{l}\text { Anyagvastagság } \\
(\mathrm{mm})\end{array}$ & 0,117 & 0,12 & 0,12 \\
\hline Művelet & vágás & vágás & vágás \\
\hline Átlagteljesítmény & $8-11,2 \mathrm{~W}$ & $10-12 \mathrm{~W}$ & $8,7 \mathrm{~W}$ \\
\hline $\begin{array}{l}\text { Közepes átlagtelje- } \\
\text { sítmény }\end{array}$ & $9,6 \mathrm{~W}$ & $11 \mathrm{~W}$ & $8,7 \mathrm{~W}$ \\
\hline $\begin{array}{l}M^{2} \text { közepes átlag- } \\
\text { teljesítményen } \\
\text { a szerviz adatai } \\
\text { alapján }\end{array}$ & 3,9 & 4,2 & 3,7 \\
\hline$d_{f 0}(\mu \mathrm{m})$ & 13,3 & 14,2 & 12,7 \\
\hline $\pm z_{r}(\mu \mathrm{m})$ & $\pm 33,2$ & $\pm 35,6$ & $\pm 31,7$ \\
\hline $\begin{array}{l}\text { Az átvágott falvas- } \\
\text { tagság miatt szük- } \\
\text { séges } Z_{r u ́ j}(\mu \mathrm{m})\end{array}$ & $\pm 58,5$ & \pm 60 & \pm 60 \\
\hline $\begin{array}{l}\text { Ebből kiszámolt új } \\
M^{2} \text { tényező }\end{array}$ & 6,9 & 7,1 & 7,1 \\
\hline $\begin{array}{l}\text { Ebből kiszámolt új } \\
\text { fókuszfoltátmérő } \\
(\mu \mathrm{m})\end{array}$ & 23,4 & 24 & 24 \\
\hline
\end{tabular}

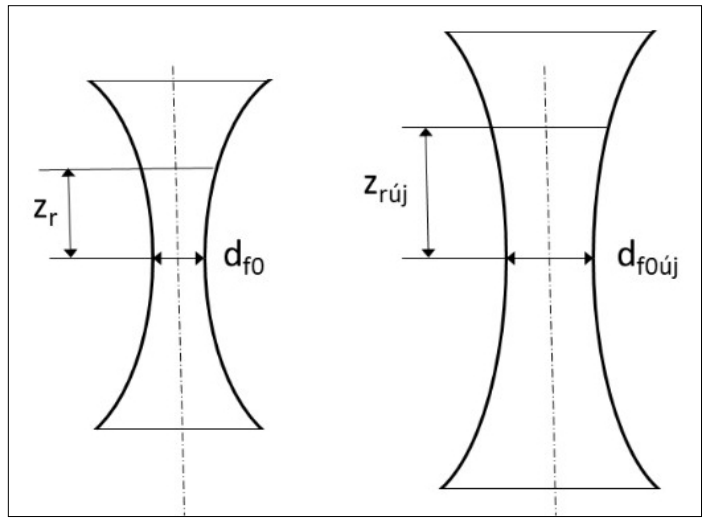

2. ábra. A fókuszfoltátmérő és a Rayleigh-hossz elméleti és becsült $M^{2}$ tényező alapján kiszámolt értékeinek szemléltetése

3. táblázat. $M^{2}$ tényező és $d_{f o}$ és $z_{r}$ elméleti és az átvágott lemez anyagvastagság alapján korrigált új értékei

\begin{tabular}{|c|c|c|}
\hline & $\begin{array}{c}\text { 4. kísérlet } \\
\text { [11] }\end{array}$ & $\begin{array}{c}\text { 5. kísérlet } \\
\text { [12] }\end{array}$ \\
\hline Anyagvastagság (mm) & 0,4 & 0,4 \\
\hline Anyaggeometria & lemez & lemez \\
\hline Anyagminőség & AISI 304L & AISI 304L \\
\hline Múvelet & vágás & vágás \\
\hline $\boldsymbol{P}_{\text {átlag }}$ & $12,5-16$ & 9,2 \\
\hline Nyalábtágító szorzó & 4 & 4 \\
\hline $\begin{array}{l}\text { Közepes átlagteljesít- } \\
\text { mény }\end{array}$ & $14,25 \mathrm{~W}$ & $9,2 \mathrm{~W}$ \\
\hline $\begin{array}{l}M^{2} \text { közepes átlagteljesít- } \\
\text { ményen a szerviz adatai } \\
\text { alapján }\end{array}$ & 4,85 & 3,84 \\
\hline$d_{f 0}$ mikrométer & 32,87 & 26,02 \\
\hline $\pm z_{r}$ mikrométer & $\pm 164,3$ & $\pm 130,12$ \\
\hline $\begin{array}{l}\text { Az átvágott falvastagság } \\
\text { miatt szükséges } z_{r u ́ j} \\
(\mu \mathrm{m})\end{array}$ & \pm 200 & \pm 200 \\
\hline $\begin{array}{l}\text { Ebből kiszámolt új } M^{2} \\
\text { tényező }\end{array}$ & 5,9 & 5,9 \\
\hline $\begin{array}{l}\text { Ebből kiszámolt új fó- } \\
\text { kuszfoltátmérő ( } \mu \mathrm{m})\end{array}$ & 40 & 40 \\
\hline
\end{tabular}

\section{5. Összefoglalás}

A cikkben a fókuszált lézernyaláb keresztmetszete két fontos jellemzőjének, a fókuszfoltátmérőnek és a Rayleigh-hossznak mint a szakirodalomban legelterjedtebb képleteiben szereplő változóknak a hatását elemeztük. A mindkét képletben szereplő, a nyalábminőséget kifejező változók egymásba való átváltását ismertetjük, 
és a szakirodalom alapján bebizonyítjuk, hogy a lézereknél a gyárilag megadott értékekhez képest a lézernyaláb optikai sugármenetében lévő lencsék hibái miatt a nyalábminőség romlani fog, tehát $M^{2}$ tényező értéke nő. A megnövekedett $M^{2}$ változó alsó határának becslésére bemutatunk egy új összefüggést, mely az átvágott anyagvastagság és a kétszeres Rayleigh-hossz mint fókuszmélység egyeztetésén alapul.

\section{Szakirodalmi hivatkozások}

[1] Kaplan A. F. H.: Theoretical Analysis of Laser Beam Cutting. Shaker Verlag, Aachen, 2002. 1214. ISBN 3-8322-0803-8

[2] Paripás B., Szabó Sz., Kocsisné Baán M., Tolvaj B., Bencs P.: Lézeresmérési és megmunkálási eljárások a gépészetben. Nemzeti Tankönyvkiadó, 2009. 66-67.

[3] Zimmermann M., Mys I., Schmidt M.: Micro cutting of thin sheets with single mode fiber lasers. Laser assisted net shape engineering 5. Proceedings of the LANE, 2007. 220-224.

[4] Harp W. R., Paleocrassas A. G., Tu J. F.: A Practical method for determining the beam profile near the focal spot. The International Journal of Advanced Manufacturing Technology, 37. (2008) 1113-1119. https://doi.org/10.1007/s00170-007-1067-z

[5] Wirth P.: Introduction to Industrial Laser Materials Processing. Hamburg, Germany, Rofin-Sinar Laser, 2000. 14-59.

[6] Hemmerich M., Thiel C., Lupp F., Hanebuth H., Weber R., Graf T.: Reduction of Focal Shift Effects in Industrial Laser Beam Welding by Means of Innovative Protection Glass Concept. 8 th International Conference on Photonic Technologies LANE 2014. Physics Procedia, 56. (2014) 681-688. https://doi.org/10.1016/j.phpro.2014.08.161

[7] Rodrigues C., Vanhove H., Duflou J. R.: Direct diode lasers for industrial laser cutting: a performance comparison with conventional fiber and $\mathrm{CO}_{2}$ technologies. 8 th International Conference on Photonic Technologies LANE 2014. Physics Procedia,
56. (2014) 901-908.

https://doi.org/10.1016/j.phpro.2014.08.109

[8] Thombansen U., Hermanns T., Stoyanov S.: Setup and Maintenance of Manufacturing Quality in $\mathrm{CO}_{2}$ Laser Cutting. $2^{\text {nd }}$ International Conference on Ramp-Up Management 2014 (ICRM). Procedia CIRP, 20. (2014) 98-102.

https://doi.org/10.1016/j.procir.2014.05.037

[9] Hashemi S. S., Sabouri S. G., Khorsandi A.: In situ measurement of laser beam quality. Applied. Physics B (2017) 123-233. Springer-Verlag GmbH Germany, 2017. https://doi.org/10.1007/s00340-017-6811-y

[10] MSZ EN ISO 1145 Optika és fotonika. Lézerek és lézerberendezések. Szakszótár és jelképek (ISO 1145:2018)

[11] Buza G.: Lézersugaras technológiák I. Edutus Főiskola, 2012. 24-29.

[12] Meszlényi Gy., Dobránszky J., Puskás Zs.: Laser cutting of high precision tubes. Material Science Forum, 589. (2008) 427-431.

https://doi.org/10.4028/www.scientific.net/ MSF.589.427

[13] Meszlényi Gy., Bella Sz., Nagy P., Dobránszky $\mathrm{J} .:$ Laser beam cutting and welding of coronary stents. BID-ISIM Welding and material testing, (2008) 14-11.

[14] Meszlényi Gy., Izápy V.: Optimization method of laser cutting parameters for high precision stainless steel tubes. In: Proceedings of the SIP 2008, $26^{\text {th }}$ International Conference Science in Practice Osijek, Horvátország, 2008. 95-97.

[15] Meszlényi Gy., Dobránszky J., Dévényi L.: Laser cutting of stainless steel thin sheets with pulsed Nd:YAG laser. 6. In: Országos Gépészeti Konferencia, Gépészet 2008, Budapest. Magyarország, Budapesti Műszaki és Gazdaságtudományi Egyetem, 2008. 1-5.

[16] Meszlényi Gy., Dobránszky J., Puskás Zs.: Role of the laser focus position in the laser beam cutting of thin stainless steel sheets. Material Science Forum, 659. (2010) 209-214. 